University of Wollongong

Research Online

Faculty of Business - Papers (Archive)

Faculty of Business and Law

$1-1-2015$

The characteristics of potential environmental volunteers: implications for marketing communications

Melanie J. Randle

University of Wollongong, mrandle@uow.edu.au

Sara Dolnicar

University of Wollongong, s.dolnicar@uq.edu.au

Follow this and additional works at: https://ro.uow.edu.au/buspapers

Part of the Business Commons

Research Online is the open access institutional repository for the University of Wollongong. For further information contact the UOW Library: research-pubs@uow.edu.au 


\title{
The characteristics of potential environmental volunteers: implications for marketing communications
}

\begin{abstract}
Many environmental organisations rely on volunteers to provide important services that would otherwise not be provided by government. However, with the substantial growth in Australia's non-profit sector, the competition for volunteers has increased significantly. Non-profit organisations are implementing marketing strategies to convince potential volunteers that their particular cause is more worthy of an individual's valuable time than other leisure activities. Most studies of volunteers focus on individuals who are already involved; however, equally important is understanding those who have not previously volunteered but who stated their intention to do so in future. This study investigates this notion in the context of environmental volunteering. Through a survey of 1318 Australians, we identify that potential environmental volunteers differ from non-environmental volunteers in terms of having: (1) stronger proenvironmental attitudes; (2) different motivations for volunteering; and (3) differing personal values. Practically, findings can inform volunteer recruitment strategies to target individuals who already have a predisposition towards environmental volunteering, resulting in more efficient spend of limited marketing dollars. Promotions that align with the motivations and values of this group are more likely to resonate with them and prompt action, and have the potential to increase the overall number of volunteers for environmental causes.
\end{abstract}

\section{Keywords}

potential, characteristics, communications, implications, marketing, volunteers, environmental

\section{Disciplines}

Business

\section{Publication Details}

Randle, M. \& Dolnicar, S. (2015). The characteristics of potential environmental volunteers: implications for marketing communications.Australasian Journal of Environmental Management, 22 (3), 329-339. 


\title{
The characteristics of potential environmental volunteers: \\ Implications for marketing communications
}

\author{
Melanie Randle ${ }^{1}$ \\ School of Management, Operations and Marketing \\ University of Wollongong \\ Wollongong NSW 2522 \\ Email mrandle@uow.edu.au \\ Phone +61 242214858
}

\section{Sara Dolnicar}

School of Tourism

University of Queensland

Brisbane QLD 4072

Emails.dolnicar@uq.edu.au

Phone + 61733656702

Keywords: environmental volunteers, recruitment, marketing, segmentation, motivations, values

Acknowledgements: This research was funded by the Australian Research Council through the Linkage Grant Scheme (LP0453682) and our industry partner, Wollongong City Council Bushcare.

\footnotetext{
${ }^{1}$ Corresponding author
} 


\begin{abstract}
Many environmental organisations rely on volunteers to provide important services that would otherwise not be provided by government. However, with the substantial growth in Australia’s nonprofit sector the competition for volunteers has increased significantly. Nonprofit organisations are implementing marketing strategies to convince potential volunteers that their particular cause is more worthy of an individual's valuable time than other leisure activities. Most studies of volunteers focus on individuals who are already involved, however equally important is understanding those who have not previously volunteered but who state their intention to do so in future. This study investigates this notion in the context of environmental volunteering. Based on a sample of 1,318 Australians we identify that potential environmental volunteers differ from non-environmental volunteers in terms of having: (1) stronger pro-environmental attitudes; (2) different motivations for volunteering; and (3) differing personal values. Practically, findings can inform volunteer recruitment strategies to target individuals who already have a predisposition towards environmental volunteering, resulting in more efficient spend of limited marketing dollars. Promotions that align with the motivations and values of this group are more likely to resonate with them and prompt action, and have the potential to increase the overall number of volunteers for environmental causes.
\end{abstract}




\section{Introduction}

Environmental issues continue to attract attention at the local, national and international levels, with four out of five Australian adults reporting they are concerned about at least one environmental problem (Australian Bureau of Statistics, 2010). However, this apparent environmental consciousness has in many cases failed to stem debate on the priority governments should attach to environmental policies (e.g. Hannam \& Wroe, 2014). In the midst of perceived government indecision and inaction, nonprofit organisations have come to the fore in the provision of important environmental restoration and support services and, as a result, a multitude of not-for-profit environmental organisations have emerged (Productivity Commission, 2010).

A scan of environmental volunteering opportunities advertised online reveals the wide range of organisations that rely on volunteers to achieve environmental objectives. These include, for example, botanic gardens and park authorities, wildlife rehabilitation centres, marine conservation organisations in coastal areas and agricultural land rehabilitation groups in rural areas (Volunteering Australia, 2014). The roles performed by these volunteers are equally varied and include gardening and maintenance, removal of invasive weed species, mapping and location of pest colonies, erection of signage and fencing and mentoring of student sustainability projects. Similar to other volunteering organisations, environmental organisations face the challenge of convincing the market of potential volunteers that their particular cause is more worthy, more interesting, and more deserving of an individual's time than other alternatives.

The National Survey of Volunteering Issues conducted by Volunteering Australia (2011) revealed that the majority of Australian volunteering organisations across all sectors are currently in need of more volunteers. This is particularly the case for environmental/animal welfare organisations, of which 78 percent are reported to be currently trying to attract more volunteers (Volunteering Australia, 2011). To successfully do this they need to take a more scientific approach to their volunteer recruitment campaigns, which involves adapting and utilising marketing techniques that have been tried and tested in the for-profit sector (Bussell \& Forbes, 2002). Suitable techniques include market segmentation and targeted advertising to reach those individuals most likely to be a good match with the specific volunteering 
experience offered. If organisations know which types of individuals are most likely to volunteer for their cause, they can produce marketing campaigns which more effectively reach these individuals and contain messages designed to engage their attention and motivate them to begin volunteering.

There are many examples of social marketing campaigns which have been successful in changing the behaviours of members of the general population - either by persuading people to discontinue unhealthy behaviours (e.g. reducing fat consumption) or commence healthy behaviours (e.g. obtaining immunisations) (Grier \& Bryant, 2005). Studies have also demonstrated the capacity for social marketing campaigns to increase rates of volunteering, for example amongst older adults (Tan et al., 2010). Environmental volunteering organisations are faced with a similar social marketing challenge: to increase the number of people who engage in the pro-social behaviour of volunteering, specifically in the context of activities that improve the natural environment.

Whilst a number of prior studies have focused on the delivery and effectiveness of environmental volunteering programs (e.g. Aslin, Mazur, \& Curtis, 2002; Savan, Morgan, \& Gore, 2003; Warburton, Marshall, Warburton, \& Gooch, 2005), to this point few researchers have attempted to identify the types of individuals likely to volunteer for environmental causes. The result is that nonprofit managers responsible for attracting volunteers have been left with scant information to make marketing-related decisions. The few prior marketingrelated or volunteer profiling studies conducted provide limited profiling information and tend to focus on individuals who already volunteer for environmental causes (e.g. Bruyere \& Rappe, 2007; Liarakou, Kostelou, \& Gavrilakis, 2011), instead of those who might become involved in future. It is this gap in knowledge that this study seeks to address. Specifically, the aims of this study are to: (1) identify individuals likely to volunteer for environmental causes in future (referred to henceforth as potential environmental volunteers); (2) identify whether they are driven purely by the organisational mission (i.e. they have stronger proenvironmental attitudes than others) or if they volunteer for a range of other reasons, and whether these motivations are different from non-environmental volunteers; and (3) provide a more comprehensive profile of these people by comparing their personal values to those of the rest of the population. 


\section{Prior research}

One attempt to profile environmental volunteers used data from the World Values Survey (Inglehart, Basanez, Diez-Medrano, Halman, \& Luijkx, 2004) to compare the characteristics of environmental and animal rights volunteers with both non-volunteers and volunteers for other causes (Randle \& Dolnicar, 2006a). Significant differences were found in relation to socio-demographics, general concerns and the factors considered important in a job. In a second (Australian) study, environmental volunteers were found to be more altruistic, had a stronger feeling of regional identity and displayed stronger pro-environmental attitudes than volunteers for other causes (Randle \& Dolnicar, 2006b). Results are useful in terms of profiling who already volunteers, but they have limited use for organisations wanting to expand their base of volunteers by attracting people who have not volunteered before but are likely to do so in future.

In terms of motivations for volunteering, most researchers agree that they are multi-faceted (Allison, Okun, \& Dutridge, 2002; Clary, Snyder, \& Ridge, 1992; Hibbert, Piacentini, \& Al Dajani, 2003). Volunteers seek a range of outcomes, both in terms of the value provided to the beneficiaries of their volunteering efforts but also the benefits they personally gain from involvement (e.g. learning new skills or socialising and meeting new people) (Burns, Reid, Toncar, Anderson, \& Wells, 2008). In their study of volunteers from non-government organisations, Martinez and McMullin (2004) compared active versus non-active volunteers and found that active volunteers were motivated by significantly stronger feelings of efficacy, while inactive volunteers were more restricted by competing commitments. Again, however, this study only included individuals who already volunteered so results are limited in their usefulness for attracting a wider range of people. While is it is likely that the mission of an environmental organisation is a key motivator for volunteers, it is also possible that a number of other motivations contribute to the decision to volunteer. What is not known is which motivations specifically characterise potential environmental volunteers when compared to the rest of the population.

Personal values has also been found relevant in terms of volunteering behavior. For example, when comparing volunteers to non-volunteers, Mahoney and Pechura (1980) found that 
volunteers place more importance on self-respect, equality and inner harmony, and Wymer (1997) found they place less importance on pleasure and salvation. Conversely in a Canadian study, Reed and Selbee (2003) found no significant differences in the values of volunteers when compared to non-volunteers and recommended the market be segmented further to reduce the level of heterogeneity present. Wymer (1997) did this by focusing on the cause the individual volunteered for. Results showed significant differences for all except one of the causes included. For example, arts and culture volunteers placed more importance on beauty, freedom and a comfortable life, and less importance on salvation. Youth development volunteers, on the other hand, placed more importance on empathy, happiness, and mature love, and less importance on inner harmony, national security and wisdom. This study did not include environmental causes, however based on this evidence it seems likely that they too will display distinct values compared to non-volunteers.

The aim of this study is to investigate whether, when compared to non-environmental volunteers, potential environmental volunteers differ in terms of:

1. their pro-environmental attitudes;

2. their motivations for volunteering; and

3. their personal values.

The strategy of market segmentation (i.e. splitting the broad population into smaller groups which share some common characteristic) is common in the commercial arena where marketing efforts are targeted towards those individuals most likely to purchase a product or service, therefore minimising time and money spent on individuals with little interest in the same product or service (e.g. Aroean \& Michaelidou, 2014; Dolnicar, 2002; Holbrook, 1996). Whilst it has taken longer for market segmentation to be accepted as a systematic tool for informing marketing strategy in the nonprofit sector, numerous authors have identified this gap and called for research to identify whether homogenous groups of donors or volunteers exist which could be the target of customised marketing campaigns (Bussell \& Forbes, 2002; Chinman \& Wandersman, 1999; Reed \& Selbee, 2000). If potential environmental volunteers are found to have unique characteristics it presents an opportunity to develop targeted marketing and recruitment campaigns. Campaigns with customised messages are more likely to resonate with the specific group being targeted and make more efficient use of limited marketing dollars. 


\section{Methods}

\section{Data collection}

Data were collected in Australia through online research panel company PureProfile, which structures the panel to be representative of the population. Panel members are recruited through multiple channels to ensure a broad cross-section of society is included (e.g. online, through newspaper advertisements and shopping centre intercepts). Invitations to complete the questionnaire were emailed to a nationally representative sample of Australians aged 18+ and the survey was available for completion for approximately four weeks. Panel members receive points as incentives for completing questionnaires which can be accumulated and redeemed for rewards through the panel company.

The data used to investigate the research questions regarding environmental volunteering formed part of a larger study which investigated volunteering behaviour more broadly (the specific questions used to conduct the analysis are included as Appendix 1). Considering the aim of this study was to understand differences between segments of the volunteering population (not estimate the size of these segments) the sample would ideally include maximum levels of heterogeneity. This data included Australian residents who associated with 14 different cultural backgrounds and was therefore ideal for examining the research questions specified. Of the 1,415 individuals who completed the questionnaire, 1,381 had not volunteered for an environmental organisation in the past 12 months. This sub-sample of participants is the focus of the present investigation.

\section{Measures}

In the process of selecting and developing measures for inclusion in this study a qualitative pre-study was conducted. This pre-study included individual interviews and group discussions with a range of people who have different perspectives on volunteering, including current volunteers for different causes, former volunteers, managers of various volunteer programs and members of the general population $(n=63)$. Participants were sourced through 
local volunteering organisations and members of the general population were recruited using random sampling at public areas such as shopping centres and also using convenience sampling. Participants were asked about their past and current volunteering behaviour, reasons for participation/non-participation and perceived outcomes of volunteering for themselves, others and the community. The managers of volunteer organisations gave their expert opinions on these issues.

The pre-study sought to identify the motivations and personal values relevant to the behaviour of volunteering. Results were used to formulate the list of motivations for volunteering. They also informed the selection of the 20 personal values most relevant to the behaviour of volunteering from the 60 values included in Schwartz's (1992) values survey (a reduced list was chosen to prevent respondent fatigue and maximise data validity). Regarding motivations, analysis of qualitative results included frequency counts of stated motivations, grouping of similar motivations and elimination of redundant items. The resultant list was also compared against prior literature on volunteer motivations (e.g. Australian Bureau of Statistics, 2006; Clary et al., 1998) to cross-check that no relevant motivation domains had been missed. Regarding personal values, qualitative data (including participant descriptions of reasons for, and outcomes of, volunteering) were analysed in light of Schwartz's 10 value types. Based on these descriptions, for each value type, the two single values which were hypothesised to characterise volunteers chosen for inclusion.

\section{Volunteering behavior}

Respondents were asked whether they had volunteered (given unpaid help to an organisation or group) in the past 12 months. Those who had volunteered were presented with a list of 11 different causes - arts/culture, business/professional, sport/recreation, emergency services, community/welfare, employee’s union, environmental, education/training/youth development, health, religious, animal welfare - and asked to indicate which one most accurately described the cause they had volunteered for.

The measurement of behavioral intention is used commonly in social psychological theories such as the Theory of Planned Behaviour (Ajzen, 1991) as a proxy for future behaviour, as intention is considered to be the immediate precursor to actual behaviour. Whist not perfectly predictive of actual behaviour it does differentiate between those individuals on whom any 
marketing dollar would be wasted and those whom there is a chance of attracting. To measure behavioural intention in this study, participants were then given the above list of 11 causes and asked which they would be likely to volunteer for in future. For this question participants could tick as many answer alternatives as were applicable, or they could also answer "none of the above".

\section{Environmental attitudes}

Environmental attitudes were measured using the New Environmental Paradigm (Dunlap, Van Liere, Mertig, \& Jones, 2000). The scale includes 15 statements relating to the environment such as "the balance of nature is delicate and easily upset" and "humans are severely abusing the environment”. Respondents were asked to indicate their extent of agreement with each statement using a five point Likert-type scale ranging from strongly disagree to strongly agree.

\section{Motivations}

Respondents were presented with the following list of 18 reasons for volunteering: I can meet different types of people, it will help my career prospects, I want to maintain services that I may use one day, there is no-one else to do the work, it makes me feel less lonely, my children are involved with the organisation, it sets a good example for others, it keeps me active, I feel like I am doing a good job, I can socialise with people who are like me, it will improve my community, I know someone who has benefited from the organisation, it gives me the chance to help others, I can support an important cause, I can build a network of contacts, I can give something back to society, I can put faith into action, and I can gain recognition within the community.

This list was developed following the qualitative pre-study and included both altruistic motivations (e.g. to give something back to society, to help others) and egoistic motivations (e.g. to keep active, to maintain services that I may use one day). Respondents who had volunteered in the past 12 months were asked to select the motivation/s that applied to them. Individuals who had not volunteered in the past 12 months were asked to select the reasons that would be important in their decision to volunteer. 


\section{Personal values}

Participants were presented with a list of 20 values, which were a reduced version of the 60item Schwartz values survey (Schwartz, 1992). The 20 single values (and value types, indicated in parentheses) were: freedom, creativity (self-direction), an exciting life, a varied life (stimulation), an enjoyable life, pleasure (hedonism), ambition, success (achievement), wealth, authority (power), national security, family security (security), politeness, honoring of parents and elders (conformity), respect for tradition, devoutness (tradition), helpfulness, loyalty (benevolence), environmental protection and equality (universalism). Participants were asked to indicate how important they felt each value was by selecting a number from zero (of no importance) to seven (extremely important).

\section{Analysis}

Of the 1,381 respondents, 399 had not volunteered for an environmental cause in the past 12 months but indicated they would consider volunteering for an environmental organisation in future - these individuals formed the sample of potential environmental volunteers. The other 982 participants indicated had not volunteered for an environmental cause in the past 12 months and also did not check the "environmental" box when asked which types of organisations they would volunteer for in future. These people formed the segment of nonenvironmental volunteers.

Analysis of Variance (ANOVA) was used to compare means for metric variables. Chi-square tests were used to identify significant differences for binary format (categorical) variables, and the $p$-values were Bonferroni corrected to account for multiple testing. All statistics reported in this article are at the 95\% confidence level or higher.

\section{Results}

\section{Pro-environmental attitudes}


An overall average score for pro-environmental attitude was calculated by adding the positive statements from New Environmental Paradigm, subtracting the negative statements and then dividing by 15. ANOVA showed significant differences between the two groups $(F=61.0$, $\mathrm{df}=1$ ). The mean score for potential environmental volunteers was 3.8, while the mean score for non-environmental volunteers was 3.5, indicating that potential environmental volunteers do have stronger pro-environmental attitudes than non-environmental volunteers.

\section{Motivations}

Chi-square tests indicated that potential environmental volunteers were significantly more likely to nominate 11 of the 18 motivations than non-environmental volunteers. These included altruistic motivations: to support an important cause (72\% compared to 53\%); give something back to society (75\% compared to 60\%); have the chance to help others (75\% compared to 64\%); set a good example for others (59\% compared to 43\%); and improve the community (63\% compared to 49\%). Potential environmental volunteers were also significantly more likely to nominate a number of egoistic reasons for volunteering: meeting different types of people (59\% compared to 46\%); socialising with people who are similar (43\% compared to 33\%); keeping active (52\% compared to $42 \%$ ); putting faith into action (30\% compared to $21 \%$ ); to feel they are doing a good job (59\% compared to $49 \%$ ); and to take their mind off other things (33\% compared to 24\%). These results are depicted graphically in Figure 1, asterisks (*) indicate significant differences between groups.

Figure 1: Motivations of potential environmental volunteers versus non-environmental volunteers 


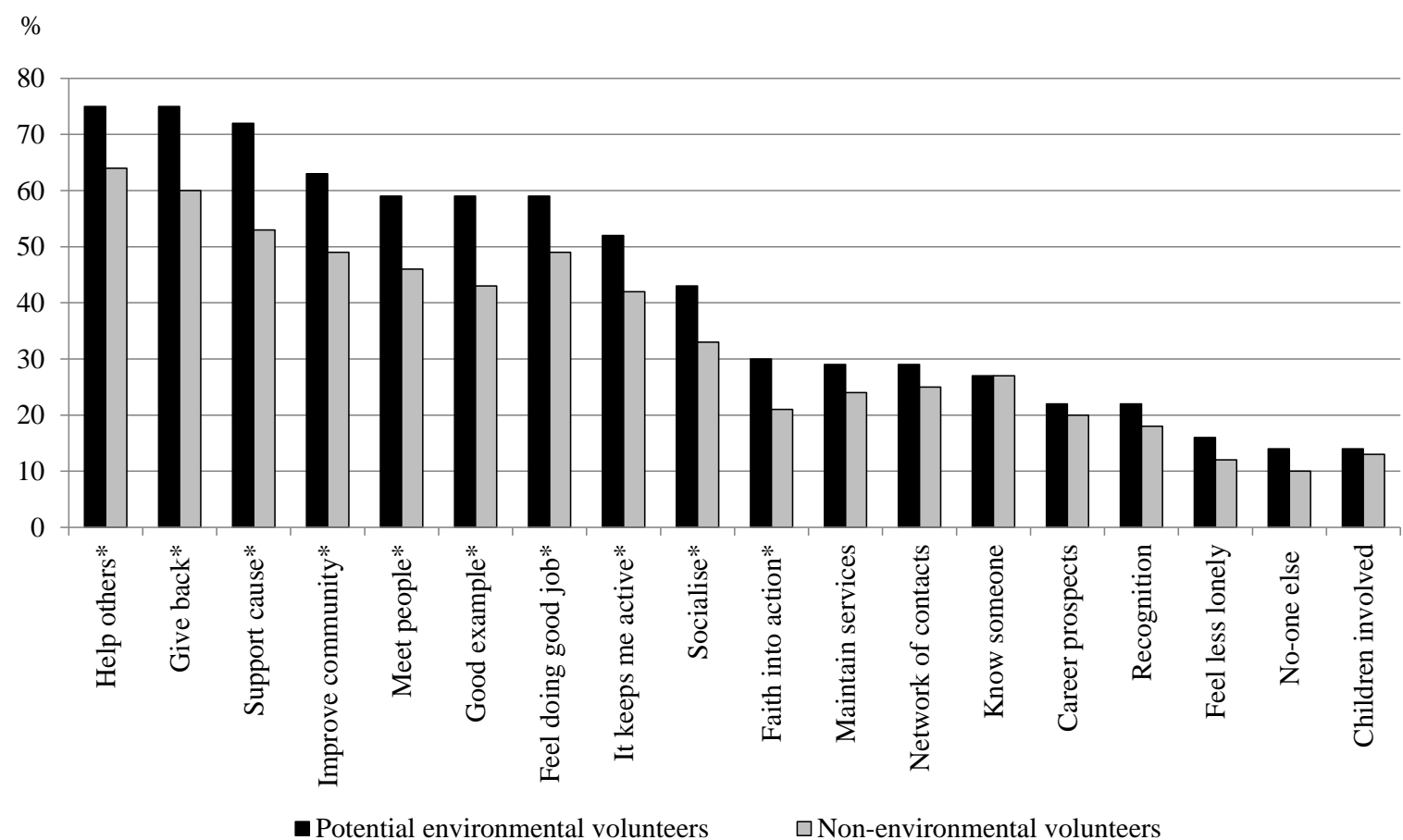

\section{Personal values}

ANOVA revealed significant differences in mean ratings for eight of the 20 values measured.

Potential environmental volunteers rated only one value significantly lower than nonenvironmental volunteers; this was authority (5.03 compared to 5.29; $\mathrm{F}=5.90, \mathrm{df}=1$ ). For seven other values, however, potential environmental volunteers rated them as more important than non-environmental volunteers. The more important values for potential environmental volunteers were: a varied life (5.46 compared to 5.27; $\mathrm{F}=4.40, \mathrm{df}=1$ ); freedom (6.07 compared to 5.86; $\mathrm{F}=6.23$, $\mathrm{df}=1$ ); helpfulness (5.43 compared to 5.17; $\mathrm{F}=7.66$, $\mathrm{df}=1$ ); an exciting life (5.47 compared to 5.24; $\mathrm{F}=5.62$, $\mathrm{df}=1$ ); creativity (5.38 compared to 5.09; $\mathrm{F}=9.23, \mathrm{df}=1$ ); equality (5.99 compared to $5.68 ; \mathrm{F}=12.60, \mathrm{df}=1$ ); and, perhaps not surprisingly, environmental protection (5.72 compared to 4.90; $\mathrm{F}=76.50, \mathrm{df}=1$ ). These results are graphically depicted in Figure and the values for which significant differences were identified are marked with an asterisk (*).

Figure 2: Values of potential environmental volunteers versus non-environmental volunteers. 


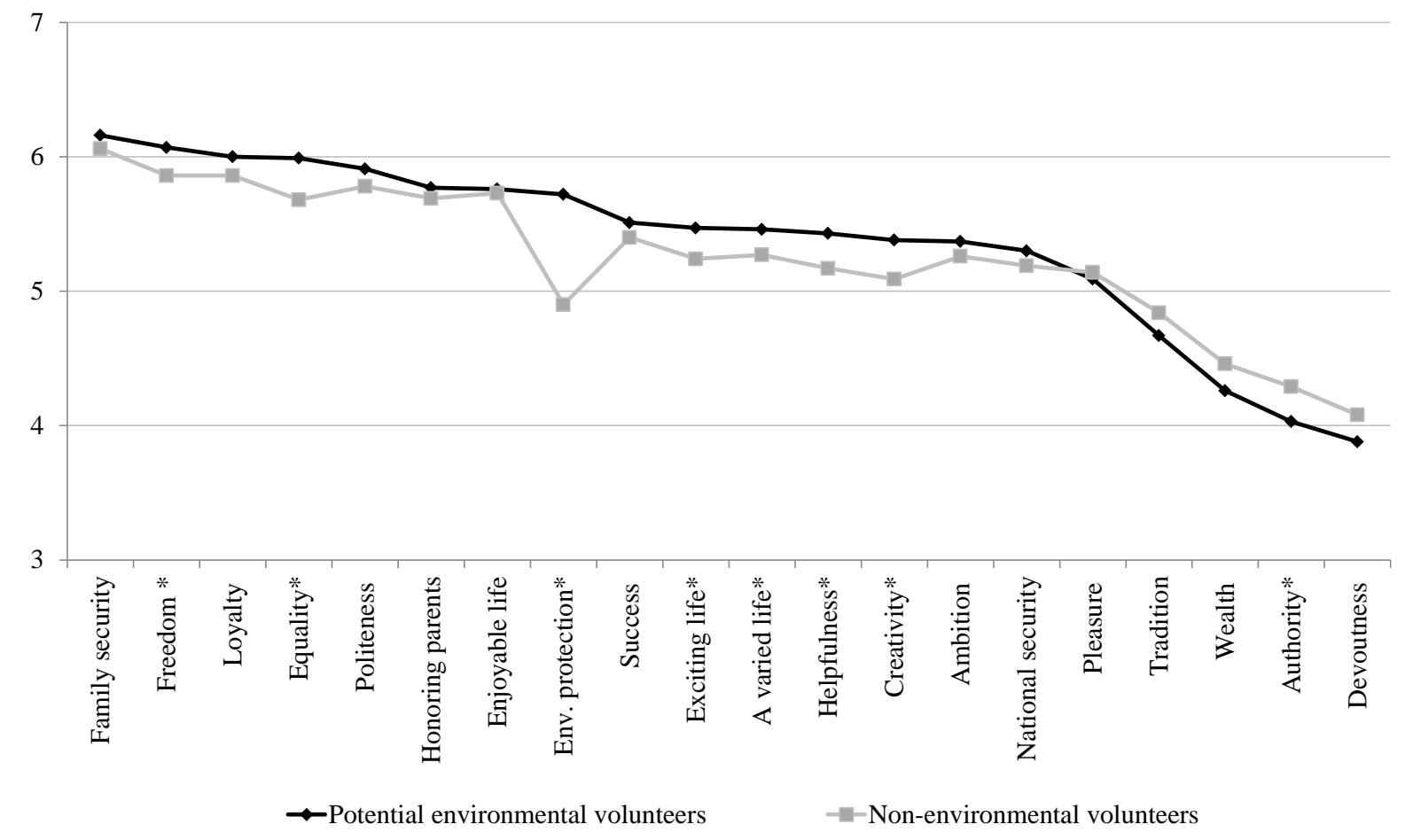

\section{Discussion and implications}

This empirical study sought to extend knowledge beyond those people who currently volunteer for environmental causes and gain insight into those people who have not yet volunteered but are more likely than the general population to do so in future.

Individuals who would consider volunteering for an environmental cause - the potential environmental volunteers - were found to have stronger pro-environmental attitudes, suggesting that they are attracted and motivated by the mission of environmental organisations. However, they are also motivated by a range of other altruistic and egoistic factors (e.g. helping others and meeting new people), and also place higher importance on selected personal values than do the rest of the population (including freedom, equality, environmental protection and leading an exciting and varied life).

Results are practically useful for managers responsible for attracting volunteers to environmental organisations. Firstly, marketing communications messages should explicitly emphasise the environmental mission of the organisation and the positive impact of its 
activities on the natural environment, as these messages are likely to be motivating for individuals with strong pro-environmental attitudes.

However, the fact that potential environmental volunteers are driven by a wide range of other motivations means that highlighting other benefits of involvement is likely to make the experience even more appealing for this segment of the market. Communications should also feature altruistic benefits of involvement, for example, the opportunity to support an important global cause, to make tangible improvements to the local area, and the positive impact environmental causes will have on quality of life for future generations. Similarly, promoting a range of egoistic benefits may motivate potential environmental volunteers, for example promoting volunteering as a social exercise, which gives volunteers the opportunity to meet new people and make friends with others who have similar values and attitudes. In addition, the fact that environmental volunteering typically involves outdoor physical work has the added benefit of contributing to an active, healthy lifestyle. This may, for example, be of particular interest to the large segment of the population that is approaching or at retirement age who are seeking activities to keep them active, healthy and useful. Similarly, the values that potential environmental volunteers view as important can be incorporated into promotional campaigns, for example volunteering as a way of leading an exciting and varied life and helping to ensure the environment is maintained for all to enjoy in future.

Theoretically, findings support previous studies which acknowledge heterogeneity within the market of volunteers and identify segments of volunteers with common characteristics that make them suitable for targeted marketing strategies (Dolnicar \& Randle, 2007; Randle \& Dolnicar, 2009; Wymer, 1997). This study makes a unique contribution to the growing body of literature in the area of environmental volunteering because it specifically examines those individuals likely to become involved in future - or the future pool of environmental volunteers. Understanding this segment of the population provides a valuable opportunity for environmental organisations to increase their overall numbers of volunteers and attract new people who have not been involved before. This is an important issue for many environmental organisations because the competition for volunteers is increasing (Bussell \& Forbes, 2002; Simpson, Lefroy, \& Tsarenko, 2011) and without reliable information and tools to recruit and attract sufficient volunteers many would cease to exist.

The strategy suggested here -segmenting the market to identify the group most likely to respond to marketing messages, and then targeting communications directly at them - has 
been repeatedly demonstrated as a more effective and efficient use of marketing funds than generic communications aimed at the entire population. This is particularly salient in the case of nonprofit environmental organisations which often find themselves with limited funds to spend on marketing-related activities. 


\section{References}

Ajzen, I 1991, The theory of planned behaviour, Organizational Behavior and Human Decision Processes, vol.50, no.2, pp. 179-211.

Allison, LD, Okun, MA, \& Dutridge, KS 2002, Assessing volunteer motives: A comparison of an open-ended probe and likert rating scales, Journal of Community and Applied Social Psychology, vol.12, no.4, pp. 243-255.

Aroean, L, \& Michaelidou, N 2014, A taxonomy of mobile phone consumers: Insights for marketing managers, Journal of Strategic Marketing, vol.22, no.1, pp. 73-89.

Aslin, H, Mazur, NA, \& Curtis, AL 2002, Identifying regional skill and training needs for integrated natural resource management planning, Bureau of Rural Sciences, Canberra.

Australian Bureau of Statistics 2006, Voluntary work australia, viewed 31 January 2014, http://www.ausstats.abs.gov.au/ausstats/subscriber.nsf/0/C52862862C082577CA2573 1000198615/\$File/44410_2006.pdf.

Australian Bureau of Statistics 2010, Environmental awareness and action, viewed 1 March 2014, file://C:/Users/mrandle/Documents/Melanie/Literature/Volunteering/Australian\%20B ureau\%20of\%20Statistics\%2010.pdf.

Bruyere, B, \& Rappe, S 2007, Identifying the motivations of environmental volunteers, Journal of Environmental Planning and Management, vol.50, no.4, pp. 503-516. 
Burns, DJ, Reid, J, Toncar, M, Anderson, C, \& Wells, C 2008, The effect of gender on the motivation of members of generation y college students to volunteers, Journal of Nonprofit and Public Sector Marketing, vol.19, no.1, pp. 99-118.

Bussell, H, \& Forbes, D 2002, Understanding the volunteer market: The what, where, who and why of volunteering, International Journal of Nonprofit and Voluntary Sector Marketing, vol.7, no.3, pp. 244-257.

Chinman, MJ, \& Wandersman, A 1999, The benefits and costs of volunteering in community organisations: Review and practical implications, Nonprofit and Voluntary Sector Quarterly, vol.28, no.1, pp. 46-64.

Clary, EG, Ridge, RD, Stukas, AA, Snyder, M, Copeland, J, Haugen, J, \& Miene, P 1998, Understanding and assessing the motivations of volunteers: A functional approach, Journal of Personality and Social Psychology, vol.74, no.6, pp. 1516-1530.

Clary, EG, Snyder, M, \& Ridge, R 1992, Volunteers' motivations: A functional strategy for the recruitment, placement, and retention of volunteers, Nonprofit Management and Leadership, vol.2, no.4, pp. 333-350.

Dolnicar, S 2002, A review of data-driven market segmentation in tourism, Journal of Travel and Tourism Marketing, vol.12, no.1, pp. 1-22.

Dolnicar, S, \& Randle, M 2007, What moves which volunteers? Psychographic heterogeneity among volunteers in australia, Voluntas: International Journal of Voluntary and Nonprofit Organizations, vol.18, no.2, pp. 135-155.

Dunlap, RE, Van Liere, KD, Mertig, AG, \& Jones, RE 2000, Measuring endorsement of the new ecological paradigm: A revised nep scale, Journal of Social Issues, vol.56, no.3, pp. 425-442. 
Grier, SA, \& Bryant, CA 2005, Social marketing in public health, Annual Review of Public Health, vol.26, pp. 319-339.

Hannam, P, \& Wroe, D 2014, Record sparks hot debate on tony abbott's climate policy, Hibbert, S, Piacentini, M, \& Al Dajani, H 2003, Understanding volunteer motivation for participation in a community-based food cooperative, International Journal of Nonprofit and Voluntary Sector Marketing, vol.8, no.1, pp. 30-42.

Holbrook, MB 1996, Market segmentation based on age and attitude toward the past: Concepts, methods, and findings concerning nostalgic influences on customer tastes, Journal of Business Research, vol.1996, no.37, pp. 1.

Inglehart, R, Basanez, M, Diez-Medrano, J, Halman, L, \& Luijkx, R 2004, Human beliefs and values: A cross-cultural sourcebook based on the 1999-2002 values surveys, Siglo XXI Editores, Mexico.

Liarakou, G, Kostelou, E, \& Gavrilakis, C 2011, Environmental volunteers: Factors influencing their involvement in environmental action, Environmental Education Research, vol.17, no.5, pp. 651-673.

Mahoney, J, \& Pechura, CM 1980, Values and volunteers: Axiology of altruism in a crisis center, Psychological Reports, vol.47, no.2, pp. 1007-1012.

Martinez, TA, \& McMullin, SL 2004, Factors affecting decisions to volunteer in nongovernmental organizations, Environment and Behavior, vol.36, no.1, pp. 112126.

Productivity Commission 2010, Contribution of the not-for-profit sector, Commonwealth of Australia, Canberra. 
Randle, M, \& Dolnicar, S 2006a, Who donates time to the benefit of the environment and animal rights? Profiling volunteers from an international perspective, Australasian Nonprofit and Social Marketing (ANSM) Conference Proceedings, Newcastle, New South Wales.

Randle, M, \& Dolnicar, S 2006b, Environmental volunteers: Are they driven by altruism and a strong feeling of regional identity?, Australasian Nonprofit and Social Marketing (ANSM) Conference CD Proceedings, Newcastle, New South Wales.

Randle, M, \& Dolnicar, S 2009, Understanding the australian environmental volunteering market: A basis for behavioural change and a sustainable future, Australasian Marketing Journal, vol.17, no.4, pp. 192-203.

Reed, PB, \& Selbee, K 2003, Do people who volunteer have a distinctive ethos? A canadian study, in P Dekker \& L Halman (ed) The values of volunteering: Cross-cultural perspectives, Kluwer Academic/Plenum Publishers, New York, NY.

Reed, PB, \& Selbee, LK 2000, Distinguishing characteristics of active volunteers in canada, Nonprofit and Voluntary Sector Quarterly, vol.29, no.4, pp. 571-592.

Savan, B, Morgan, AJ, \& Gore, C 2003, Volunteer environmental monitoring and the role of the universities: The case of citizens' environment watch, Environmental Management, vol.31, no.5, pp. 561-568.

Schwartz, SH 1992, Universals in the content and structure of values: Theoretical advances and empirical tests in 20 countries, in MP Zanna (ed) Advances in experimental social psychology, Academic Press, New York.

Simpson, D, Lefroy, K, \& Tsarenko, Y 2011, Together and apart: Exploring structure of the corporate-npo relationship, Journal of Business Ethics, vol.101, no.2, pp. 297-311. 
Tan, EJ, Tanner, EK, Seeman, TE, Xue, Q-L, Rebok, GW, Frick, KD, Carlson, MC, Wang, T, Piferi, RL, McGill, S, Whitfield, KE, \& Fried, LP 2010, Marketing public health through older adult volunteering: Experience corps as a social marketing intervention, American Journal of Public Health, vol.100, no.4, pp. 727-734.

Volunteering Australia 2011, National survey of volunteering issues, viewed 5 March 2014, http://www.volunteeringaustralia.org/wpcontent/files_mf/1377045635VANSVI2011.pdf.

Volunteering Australia 2014, Environmental volunteering opportunities in australia, viewed 21 March 2014, http://govolunteer.com.au.

Warburton, J, Marshall, S, Warburton, K, \& Gooch, M 2005, Information-related constraints on the effectiveness of environmental volunteers: A case study, Australian Journal on Volunteering, vol.10, no.1, pp. 24-31.

Wymer, WW 1997, Segmenting volunteers using values, self-esteem, empathy, and facilitation as determinant variables, Journal of Nonprofit and Public Sector Marketing, vol.5, no.2, pp. 3-28. 


\section{Appendix 1 - Survey questions}

We would like to ask you about giving unpaid help - in the form of time or service - to organisations or groups. Examples of organisations or groups are welfare groups, local community organisations, religious groups, schools, sporting or social clubs, or cultural organisations.

\section{Past volunteering behaviour}

In the past 12 months have you given unpaid help to (or volunteered for) an organisation or group? (please tick one only)

$\square$ No

$\square$ Yes, at least once a week

$\square$ Yes, at least once a fortnight

$\square$ Yes, at least once a month

$\square$ Yes, several time a year

$\square$ Yes, less than several time a year

[If yes] Which one of the following most closely describes the type of organisation or group? (If you have given unpaid help to more than one organisation or group in the past 12 months please answer in relation to the organisation or group to which you have given the most help).

$\square \quad$ Arts/culture

$\square \quad$ Business/professional

$\square \quad$ Employees' union

$\square \quad$ Community/welfare

$\square \quad$ Education/training/youth development

$\square \quad$ Health

$\square \quad$ Environmental

$\square \quad$ Animal welfare

$\square \quad$ Emergency services

$\square \quad$ Religious

$\square$ Sport/recreation

\section{Future volunteering behaviour}

Which of the following types of organisations or groups (if any) would you be most likely to give unpaid help to, that is, volunteer for? (tick as many as are applicable).

$\square \quad$ Arts/culture

$\square$ Business/professional

$\square \quad$ Employees' union

$\square \quad$ Community/welfare

$\square \quad$ Education/training/youth development

$\square \quad$ Health

$\square \quad$ Environmental

$\square \quad$ Animal welfare

$\square \quad$ Emergency services

$\square \quad$ Religious

$\square \quad$ Sport/recreation

$\underline{\text { OR }} \square$ None of the above 


\section{Environmental attitudes}

Listed below are statements about the relationship between humans and the environment. For each one, please indicate the extent to which you agree or disagree with it by ticking the appropriate box.

\begin{tabular}{|c|c|c|c|c|c|}
\hline & & & & & \\
\hline We are approaching the limit of the number of people the earth can support & $\square$ & $\square$ & $\square$ & $\square$ & $\square$ \\
\hline Humans have the right to modify the natural environment to suit their needs & $\square$ & $\square$ & $\square$ & $\square$ & $\square$ \\
\hline When humans interfere with nature it often produces disastrous consequences & $\square$ & $\square$ & $\square$ & $\square$ & $\square$ \\
\hline Human ingenuity will ensure that we do not make the earth unlivable & $\square$ & $\square$ & $\square$ & $\square$ & $\square$ \\
\hline Humans are severely abusing the environment & $\square$ & $\square$ & $\square$ & $\square$ & $\square$ \\
\hline The earth has plenty of natural resources if we just learn how to develop them & $\square$ & $\square$ & $\square$ & $\square$ & $\square$ \\
\hline Plants and animals have as much right as humans to exist & $\square$ & $\square$ & $\square$ & $\square$ & $\square$ \\
\hline $\begin{array}{l}\text { The balance of nature is strong enough to cope with the environmental } \\
\text { impacts of modern industrial nations }\end{array}$ & $\square$ & $\square$ & $\square$ & $\square$ & $\square$ \\
\hline Despite our special abilities humans are still subject to the laws of nature & $\square$ & $\square$ & $\square$ & $\square$ & $\square$ \\
\hline $\begin{array}{l}\text { The so-called “ecological crisis” facing humankind has been greatly } \\
\text { exaggerated }\end{array}$ & $\square$ & $\square$ & $\square$ & $\square$ & $\square$ \\
\hline The earth is like a spaceship with very limited room and resources & $\square$ & $\square$ & $\square$ & $\square$ & $\square$ \\
\hline Humans were meant to rule over the rest of nature & $\square$ & $\square$ & $\square$ & $\square$ & $\square$ \\
\hline The balance of nature is delicate and easily upset & $\square$ & $\square$ & $\square$ & $\square$ & $\square$ \\
\hline $\begin{array}{l}\text { Humans will eventually learn enough about how nature works to be able to } \\
\text { control it }\end{array}$ & $\square$ & $\square$ & $\square$ & $\square$ & $\square$ \\
\hline $\begin{array}{l}\text { If things continue on their present course, we will soon experience a major } \\
\text { ecological catastrophe }\end{array}$ & $\square$ & $\square$ & $\square$ & $\square$ & $\square$ \\
\hline
\end{tabular}

\section{Personal values}

Below is a list of values that you may or may not feel are personally important to you. Please consider this list carefully and indicate the extent to which each one is important to you in your life by circling the appropriate number:

\begin{tabular}{|c|c|c|c|c|c|c|c|c|}
\hline & $\begin{array}{c}\text { Of no } \\
\text { importance }\end{array}$ & & & & & & & $\begin{array}{l}\text { remely } \\
\text { ortant }\end{array}$ \\
\hline Authority (the right to lead or command) & 0 & 1 & 2 & 3 & 4 & 5 & 6 & 7 \\
\hline Success (achievement of goals) & 0 & 1 & 2 & 3 & 4 & 5 & 6 & 7 \\
\hline Pleasure (gratification of desires) & 0 & 1 & 2 & 3 & 4 & 5 & 6 & 7 \\
\hline $\begin{array}{l}\text { A varied life (filled with challenge, novelty and } \\
\text { change) }\end{array}$ & 0 & 1 & 2 & 3 & 4 & 5 & 6 & 7 \\
\hline Freedom (freedom of action and thought) & 0 & 1 & 2 & 3 & 4 & 5 & 6 & 7 \\
\hline Environmental protection (preserving nature) & 0 & 1 & 2 & 3 & 4 & 5 & 6 & 7 \\
\hline Helpfulness (working for the welfare of others) & 0 & 1 & 2 & 3 & 4 & 5 & 6 & 7 \\
\hline $\begin{array}{l}\text { Respect for tradition (preservation of time-honoured } \\
\text { customs) }\end{array}$ & 0 & 1 & 2 & 3 & 4 & 5 & 6 & 7 \\
\hline Politeness (courtesy, good manners) & 0 & 1 & 2 & 3 & 4 & 5 & 6 & 7 \\
\hline $\begin{array}{l}\text { National security (protection of my nation from } \\
\text { enemies) }\end{array}$ & 0 & 1 & 2 & 3 & 4 & 5 & 6 & 7 \\
\hline Wealth (material possessions, money) & 0 & 1 & 2 & 3 & 4 & 5 & 6 & 7 \\
\hline Ambition (hardworking, aspiring) & 0 & 1 & 2 & 3 & 4 & 5 & 6 & 7 \\
\hline An enjoyable life (enjoying food, sex, leisure, etc.) & 0 & 1 & 2 & 3 & 4 & 5 & 6 & 7 \\
\hline An exciting life (stimulating experiences) & 0 & 1 & 2 & 3 & 4 & 5 & 6 & 7 \\
\hline Creativity (uniqueness, imagination) & 0 & 1 & 2 & 3 & 4 & 5 & 6 & 7 \\
\hline Equality (equal opportunity for all) & 0 & 1 & 2 & 3 & 4 & 5 & 6 & 7 \\
\hline
\end{tabular}




\begin{tabular}{|lllllllll|}
\hline Loyalty (faithfulness to friends, group) & 0 & 1 & 2 & 3 & 4 & 5 & 6 & 7 \\
\hline Devoutness (holding to religious faith and beliefs) & 0 & 1 & 2 & 3 & 4 & 5 & 6 & 7 \\
\hline Honouring of parents and elders (showing respect) & 0 & 1 & 2 & 3 & 4 & 5 & 6 & 7 \\
\hline Family security (safety for loved ones) & 0 & 1 & 2 & 3 & 4 & 5 & 6 & 7 \\
\hline
\end{tabular}

\section{Motivations}

Below is a list of reasons for giving unpaid help. If you have given, or are currently giving, unpaid help please indicate which of these reasons apply to you. If you have not given unpaid help before, please indicate which of the following reasons would be important in your decision of whether to give unpaid help. (tick as many as are applicable)

$\square$ I can meet different types of people

$\square$ It will help my career prospects

$\square$ I want to maintain services that I may use one day

$\square$ There is no-one else to do the work

$\square$ It makes me feel less lonely

$\square$ My children are involved with the organisation

$\square$ It sets a good example for others

$\square$ It keeps me active

$\square$ I feel like I am doing a good job

$\square$ I can socialise with people who are like me

$\square$ It will improve my community

$\square$ I know someone who has benefited from the organisation

$\square$ It gives me the chance to help others

$\square$ I can support an important cause

$\square$ I can build a network of contacts

$\square$ I can give something back to society

$\square$ I can put faith into action

$\square$ I can gain recognition within the community 